\title{
Eurocentrism and the Contribution of Ibn Khaldun to the Growth of Sociology
}

\author{
Aboobacker Rameez ${ }^{1}$ \\ ${ }^{1}$ Department of Sociology, South Eastern University of Sri Lanka, Oluvil, Sri Lanka \\ Correspondence: Aboobacker Rameez, Department of Sociology, South Eastern University of Sri Lanka, Oluvil, \\ Sri Lanka. E-mail: arameez@seu.ac.lk
}

Received: September 4, 2018

Accepted: October 3, $2018 \quad$ Online Published: November 29, 2018

doi:10.5539/jsd.v11n6p41

URL: https://doi.org/10.5539/jsd.v11n6p41

\begin{abstract}
It is generally believed that sociology originated in Europe in the $19^{\text {th }}$ century and the paternity of the discipline is commonly attributed to the French sociologist August Comte. However, reflections of a sociological nature were observed and found in the work of $14^{\text {th }}$ century North African historian and philosopher Ibn Khaldun. However, such contribution of Ibn Khaldun is little acknowledged by European scholars in their works. Therefore, this paper attempts to examine how Eurocentrism is embedded in the writing of the European scholars and unpacks the contribution of Ibn Khaldun in the growth of Sociology. In the first part of essay, I argue that the perspective of European scholars are mainly Eurocentric and parochial in their accounts on culture, language and other aspects of non-European society. In the second part of the essay, I argue Ibn Khaldun's contribution to the field of sociology is largely ignored, though his contributions dealt with the society and human character, political organization and government, differences between rural and urban populations, kinship, social solidarity, and the interplay between economic conditions and social organizations. Nevertheless, I argue that though Ibn Khaldun's ideas have hugely impressed some of European thinkers in the $19^{\text {th }}$ century prompting them to regard him as the progenitor of sociology, question remains as to how his ideas and theories have been appropriated by contemporary social scientists in their works.
\end{abstract}

Keywords: parochialism, ignorance, political organization, kinship, social solidarity

\section{Introduction}

Historical origin of sociology in the accounts of European scholars generally represents Eurocentrism, ignorance and parochialism. Eurocentrism is regarded as a profoundly rooted belief in the supremacy of Western Civilization, which can be constituted as an integral part of Western intellectual tradition. Assessment and evaluation of non-Western European societies from the perspective of Europeans with biases can also be regarded as Eurocentrism ( Alatas, 2007). This characteristic represents in the Western view of civilization and modernity, in the history of ideas and in the history of science and technology, art and medicine. The Eurocentrism, which is deemed as the Western view of non-Western cultures and civilization, does not either acknowledge or not recognize the contributions of non-Western scholars. By and large, Western attitude towards other cultures and civilizations is obnoxious and parochial. Eurocentrism is a significant manifestation of the ideology of modern capitalism (Amin, 2009) and represents the thought process of general people as well as scholars in the field of social sciences.

Sociology as a field of study is generally believed to have originated in Europe in the $19^{\text {th }}$ century and the paternity of the discipline is commonly attributed to the French sociologist and social philosopher August Comte (1798-1857). However, this view can be largely debunked given the fact that reflections on various themes that are distinctly sociological were found and observed in the works of $14^{\text {th }}$ century North African historian and philosopher Ibn Khaldun, He was a great scholar about whom so much has been written but whose sociological perspective has largely been neglected in the works of European scholars. In particular, his theoretical contribution has effectively remained marginal in the works of contemporary scholars in the Western world. This is what characterizes the modern form of Eurocentrism.

Although very few studies have focused on Eurocentrism and sociology, they have not triggered much academic discourse or knowledge on the contribution of Ibn Khaldun to growth of sociology as a field of study in social sciences. Thus, there has been a paucity of research and scholarship with critical academic fervor dealing with 
Eurocentrism and the contribution of Ibn Khaldun to sociology. As such, this paper attempts to examine how Eurocentrism is embedded in the writing of the European scholars and unpacks the contribution of Ibn Khaldun to the growth of Sociology.

\section{Methodology}

This study is mainly descriptive and interpretive in nature and relies on secondary materials such as academic journals, newspapers, reports from research and the internet sources. These sources have recorded the discourses dealing with Eurocentrism, contribution of European scholars to sociology as well as the yeoman contribution of Ibn Khaldun to the growth of the sociology. The first part of essay deals with conceptual framework of Eurocentrism and the Eurocentric understanding or thinking of European scholars embedded in their accounts on culture, language and other aspects of non-European society. The second part of the essay explores the contribution of Ibn Khaldun contribution to the growth of sociology and how far his knowledge and ideas have been appropriated by scholars in European societies and others in non-European societies to deal with socio-economic and political problems and challenges confronting the contemporary societies.

\section{Findings and Discussion}

This section focuses on the discussion of key findings concerning Eurocentrism embedded in the writing of European scholars on the culture, language and other aspects of non-European societies and their contribution towards the development of sociology as a field of study in social sciences. More importantly, the crux of the discussion in this section deals with the contribution of Ibn Khaldun to the growth of sociology in $14^{\text {th }}$ century and to what extent his contribution of knowledge and ideas have been acknowledged and appropriated by the European scholars and other scholars in non-European world to help solve the problems confronting the contemporary societies.

\subsection{Eurocentrism and the European Scholars}

According to Francis Bacon (1621), the paper, the magnetic compass, gunpowder, and printing were the key inventions that separated the modern (Western) world from the traditional world. Although each of this invention originated in China, he did not take much risk to know where and how it originated. This suggests the mediocrity and superficial understanding of Western scholar on invention made in traditional world and their continued effort to undermine such invention.

In the view of the German historian and archeologist Johann Winckelmann (1768), the 'true ideal of beauty' is witnessed only in the Greek aesthetic and artistic tradition and he is of the view, on the contrary, that Chinese art is inferior and decadent. Ironically, debunking this ethnocentric view of aesthetic and artistic tradition, Chinese were able to exert a significant influence on European art and decoration in the $18^{\text {th }}$ century.

In the perspective of the Prussian philosopher Wilhelm von Humboldt (1835), the Chinese language seemed inferior to the European languages. The same is the case with the German Philosopher Johann Gottfried Herder (1803) who was disdainful of Chinese national character. This is an instance to show the Eurocentric view of European scholar over non-European languages and their culture.

A British politician and statesman, Lord Thomas Babington Macaulay (1859), categorized the world into two: i) civilized nations and ii) barbarians; he referred to Britain representing the zenith of civilization and non-Western peoples representing barbarians. He was able to proudly declare that "a better equipped library of Europeans is far more worth than the whole literature of India and Arabia." This is another instance to show the embedded view of eurocentrism among European scholars.

Even many well-known European social scientists in $19^{\text {th }}$ century including Alexis de Tocqueville( 1859), Auguste Comte(1859), and John Stuart Mill( 1873), viewed the Chinese as inferior( Goody, 2006).

Jack Goody's book The Theft of History (2006) underlines the distasteful feature of Eurocentrism. According to his perspective, the past is presented to the present generation based on the historical innovation and invention made by scholars in the Europe, which subsequently imposed on the rest of the world. He, then, went on to elaborate that European scholars claim that some of the important institutions of contemporary times like science, democracy, capitalism and modernity were the by-product of European invention. Nevertheless, Goody's thesis underlines that European scholars has purposefully ignored or downplayed the history of the rest of the World and its inventions. As a result, the Europe has misinterpreted much of its own history. Goody contents that the claim of European scholars that the important institutions originated in Europe is historically flawed and he is of the view that they are prevalent among widespread range of human societies (Goody, 2006). In a way, Goody highlights the Eurocentric perspective of Western scholars over the cultures and other inventions made in the non-European countries. 
Much acclaimed 13-part TV documentary "Civilization" produced by Konneth Clark is apparently Eurocentric because it elevates the civilization of the West by giving an exclusive status, given the arts, architecture and philosophy of Europe over the past 100 years. Surprisingly, it has not taken much trouble to explore the impressive civilizational legacy of the non-Western world, particularly Chinese and Islamic civilization. This is something that has not attracted the attention of most of the European scholars whose thoughts were Eurocentric and parochial.

In her ground-breaking work A Sea of Languages: Rethinking Arabic Role in Medieval Literary History(2009), Maria Rosa Menocal unpacked the embedded racism and chauvinism in European literary and cultural history that has explicitly averted European scholars from acknowledging the great influence of Arabic, Islamic and Andalusian cultures on the development of European medieval literature. It is to be noted that she has underlined that the contribution of Muslim scientists, translators, and intellectuals helped preserve and disseminate the Greco-Roman heritage, particularly the scientific, cultural, literary advances in Europe with the fall of the Roman Empire. Most importantly, she argues that the influence of Arabs in medieval Europe has not necessarily limited to literature but contained music, science, philosophy, architecture, and the arts (Menocal, 2009). Argument of Menocal underlines the contribution of Arabs in the field of literature, science, philosophy, architecture and arts, which some of the European scholars have selectively failed to acknowledge. This can be couched as the Eurocentric perspective of European scholars.

\subsection{The contribution of European Scholars to the growth of Sociology}

The foundations of social sciences in the West were laid during the Enlightenment in the mid- $18^{\text {th }}$ century. The Enlightenment philosophers, such as Voltaire, Montesquieu, Buffon, Dennis Diderot, Rousseau, Jacques Turgot, Abbe de Saint-Pierre and Condorcet placed great emphasis on reason, freedom, science, education, reforms and reconstruction of society in the light of rational principles. They were greatly influenced by the scientific worldview and sought to apply the principles of the Newtonian physics to the study of human nature and society. Abbe de Saint-Pierre and Turgot developed the idea of societal progress. Turgot argued that the progress was an invariant and unique feature of human society (Manuel, 1962; Bury, 1955). Baron de Montesquieu, who was greatly inspired by the Newtonian physics, had a keen interest in discovering the order of society, which he sought to demonstrate through a typology of social structures (Aaron 1967: 19). Montesquieu argued that habits and character are greatly influenced the climate conditions and he considered this observation as equivalent to the law of gravity in physics. Some of the central themes in sociological thought, including the scientific study of society, the idea of social structure, the use of the comparative method, the inter-relationship of social institutions and the classification of societies on the basis of significant criteria, can be found in Montesquieu's work (Evans-Pritchard, 1981) The ideas of the Enlightenment philosophers had a profound influence on the social philosophers and sociologists in the $19^{\text {th }}$ century, notably August Comte. Comte was influenced by the ideas of Turgot, who argued that the human mind and society have passed through certain universal stages of evolutionary development from the theological thought the metaphysical to the scientific.

The French social philosopher Henri Saint-Simon (1760-1825) who was inspired by the Enlightenment, believed that the law of universal gravity provided a unifying principle for all physical as well as social and moral phenomena. Saint-Simon, who was deeply anguished by the upheaval and chaos that followed in the wake of the French Revolution, envisioned a science of society which would provide the guiding principles for social reconstruction. He considered this new science of society a branch of physiology, which he called 'social physiology'. Saint-Simon believed that the new order of society should be regulated and governed by professional managers and technocrats. However, the new order of society envisioned by him had little space for individual freedom and autonomy.

As an academic discipline, sociology emerged in Europe in the $19^{\text {th }}$ century. The growth of sociology in Europe was closely linked to the transformation of European societies, which brought about by industrialization, large scale migration of people from rural to urban areas, the collapse of feudal order, the emergence of new professional and mercantile classes, colonization, secularization, emergence of nation-states and democracy. The fundamental ideas of Western sociology were rooted in response to these massive changes (Nisbet, 1967). A substantial part of the vocabulary of Western sociology is rooted in this specific historical, and social context. Key sociological terms like class, democracy, nationalism, community, authority, rationalism, ideology, capitalism, modernity, bureaucracy, collectivism, utilitarianism, liberal and conservative were embedded in the context of the historical experience of Western societies and often has moral and ideological underpinnings( Ibid: 23)

The development of sociology in the United States from the mid- $19^{\text {th }}$ century till the outbreak of the World War I 
was greatly influenced by the massive changes that occurred in the American Society. These included the consequences of the civil war, industrialization, and urbanization, the assimilation of migrants from Europe and integration of African-Americans, during the formative period, sociology in the US was substantially influenced by the Christian project of social reform. In the early decades of the $20^{\text {th }}$ century, much of sociological research in the US was concerned with social problems arising out of industrialization, migration, urbanization. These included poverty, crime, delinquency, and rising divorce rates ( Vidich and Lyman, 1985; Turner, 1989; Wells and Picou, 1981).

Eurocentric baggage has been identified as a grave limitation of Western sociology. Sociologists claim that their discipline is preeminently comparative and Universalist in character. However, their claim is not corroborated or marched by the professional literature and theoretical propositions in mainstream sociology. All the standard textbooks in the subject, which are written mostly by the American sociologists, generally focus on themes and issues that are rooted in the context of Western societies, with passing references to India, China or Latin America. An estimated three-fourth of sociological writings are concentrated on American society.

A specific variant of Eurocentrism-'Judaeocentrism'-is found in the writings of some American, European and Israeli sociologists of Jewish descent. A striking example is provided by the views of a prominent Polish-born Israeli sociologist S.N.Eisentadt(1923-2010), winner of several coveted international prizes, honorary member of the American and European Universities. While writing about the events surrounding the creation of the state of Israel in 1848, Eisentadt highlighted the death of about 6000 Israeli soldiers in the 1947-1948 war but did not say a word about the thousands of Palestinians who were killed and displaced from their ancestral villages by the Israeli and Zionist fighters( Haller, 2015). This is an instance to argue that the Jewish sociologists are parochial, discriminative and prejudicial on the part of their sociological analysis concerning the killing, massacres, civil war and conflict.

General macro-structural theories in American sociology, which purport to be comparative and cross-cultural, are in fact largely parochial and are generalized and extrapolated from American experience to the rest of the world. One of the generalizations preferred by American gender theorists is that women do not participate in war. Maria Cole, a Polish historian and sociologist who has worked in Poland, England, USA, and Australia and has collected a good deal of historical and empirical evidence from Poland, has shown that this generalization does not hold in the case of Poland and other European societies. She has shown, on the basis of historical evidence, that women have played a substantial role in wars, insurrections, rebellion in Poland over the past two centuries. Cole argues that theories of gender inequality formulated by American sociologists are inadequate in the context of gender relations in societies other than the US.

There is a surprising ignorance among Western sociologists about multiethnic societies in Africa, Asia and Latin America. In his excellent and widely-read textbook 'Sociology', British sociologist Antony Giddens writes that "Jews do not eat pork, Hindus eat pork but avoid beef" (Giddens, 2001). The statement that Hindus eat pork but avoid beef is only half true. Generally, Hindu castes and communities avoid both pork and beef.

\subsection{Contribution of Ibnu Khaldun in the Growth of Sociology}

As discussed above, Western accounts of the historical origins of Sociology are generally colored by Eurocentrism, ignorance and parochialism. It is generally believed that sociology originated in Europe in the $19^{\text {th }}$ century and the paternity of the discipline is commonly attributed to the French sociologist and social philosopher August Comte (1798-1857). This is an erroneous view. To be precise, the reflections of a sociological nature were found in earlier times and in different parts of the world. George Ritzer has rightly observed that "scholars were doing sociology long ago and in other parts of the world too (Ritzer, 1992)

As such, works on sociology were found in the world of $14^{\text {th }}$ century North African historian and philosopher Ibn Khaldun and thus it emerged as a systematic field of inquiry. Ibn Khaldun was born in an Arab family in Tunis in $1332 \mathrm{CE}$. His significant contribution on society reflected in his monumental history of mankind, known as Kitab al-Ibar.( Momin, 2015)

Works of Ibn Khaldun on different themes that are distinctly sociological in nature are found in the Muquaddimah, or Prolegomena, which constitutes the first subjects, including the influence of environmental conditions on society and human character, different forms of political organization and government, particularly the rise and decline of states, differences between rural and urban populations, kinship, social solidarity(asabiyya), and the interplay between economic conditions and social organizations. His thoughts also focus on education and knowledge too (Alatas, 2013). His works on the nature of state, state-society relations, secularism and fundamentalism, and knowledge and education are fundamentally essential to explore and analyze the problems confronting the contemporary societies in the World. He not only relied on secondary 
sources for data collection and information relevant to society, but on personal observations and experiences too, in order to ensure accuracy and reliability in his works. This goes to say that his writings concerning human behavior and society originated during the $14^{\text {th }}$ century, much before the Western scholars discovered a discipline called sociology. Hence, his main contribution in the development of sociology as a discipline is largely ignored by popular Western sociologists in their writings.

Nevertheless, the pioneering contribution of Ibn-Khaldun to the growth of sociology in $14^{\text {th }}$ century is duly acknowledged by some European scholars including historians and sociologists and thus they elevated him as a progenitor of sociology. Therefore, ignoring them or failing to acknowledge their contribution on Ibn Khaldun would be regarded as a gross generalization. His major scholarly work called Muquaddimah was translated to French in 1863 and to English in 1958 by European scholars like De Slane and by Franz respectively. A popular scholar like A.J.Toynbee(1962) has referred to the Prolegomena as " undoubtedly the greatest work of its kind that has ever been created by any mind in any time or place (Toynbee, 1962). In his book on Sociological Essays, the Austrian sociologist Ludwig Gumplowicz (1909) has given a due place to Ibn Khaldun by including a chapter on Ibn Khaldun. Among many other sociologists who regarded Ibn Khaldun as the father of Sociology, Pitirim Sorokin, C.C.Zimmerman, and C.J.Galpin are significant. A well-known Russian American sociologist Pitirim Sorokin described his work on the Prolegomena as the pioneer systematic discourse on sociology (Sorokin, 1962). More importantly, in their authoritative history of sociology, H.E.Barnes and Howard Becker have regarded Ibn Khaldun as "the greatest among the early modern sociologists" (Barnes and Becker, 1938). Ernest Gellner has been identified as one of the popular British sociologist and has contributed enormously to the growth of sociological theories and concepts. He has maintained that Ibn Khaldun is a prominent deductive sociologist and a pioneering advocate of the method of ideal types and the greatest sociologist of Islam ( Gellner, 1983). This suggests the degree of recognition and acknowledgement Ibn Khaldun has received among the European scholars thanks to his pivotal contribution to the growth of sociology in $14^{\text {th }}$ century. However, the question remains as to how Ibn Khaldun's theories have been appropriated by European scholars in their own works on sociology and other social sciences.

\section{Conclusion}

Ibn Khaldun has been considered one the pioneers of Muslim scholars of the pre-modern period, since he founded what he called as the science of human society or social organization. It dealt with new methodology for writing history and understanding the causes of events. Although he laid the foundation for the growth of sociology during the $14^{\text {th }}$ century, his contribution toward the field of study is little acknowledged by many scholars in the Europe. Among the many reasons attributed to this tendency, Eurocentrism has largely been identified one of fundamental reasons for it.

While the earlier form of Eurocentrism is characterized by racism and stereotype of non-Western societies, the modern form of Eurocentrism is regarded as the neglect of thinking/theories or ideas that originate from non-European societies. Here, in the case of Ibn Khaldun, the problem is not the lack of knowledge about Ibn Khaldun, but the way in which knowledge and contribution of Ibn Khaldun is appropriated by scholars in the European world to the development of social sciences. Most importantly, the theoretical knowledge Ibn Khaldun developed in his works has rarely been used in the contemporary historical, sociological and empirical works of scholars in the Western world. This is what characterizes the new form of Eurocentrism and this is where the problem of Eurocentrism lies, particularly in the case of Ibn Khaldun as the founder of sociology. However, it is poignant to note that his ideas and theories have had little impact on the development of Muslim thought for several centuries, because of unknown reasons. To be precise, it is remarkable that no indigenous schools or universities in non-European world including Arab world have ever produced Khaldunian social science. By contrast, his ideas and theories have enormously convinced and impressed some of the European thinkers from the nineteenth century on. This, indeed, prompted them to regard Ibn Khaldun a progenitor of sociology and modern historiography as discussed above. However, the most important question remains as to what extent the knowledge or ideas produced Ibn Khaldun have been appropriated by scholars in the European world in their accounts on sociology or other social sciences.

\section{References}

Alatas, S. F. (2007). Historical Sociology of Muslim Societies: Khaldunian Applications. International Sociology, 22(1), 267-268. https://doi.org/10.1177/0268580907076570

Alatas, S. F. (2013). Markers of Islamic Civilization: Ibn Khaldun. New Delhi, India: Oxford University Press. https://doi.org/10.1093/acprof:oso/9780198090458.001.0001

Amin, S. (2009). Eurocentrism. Modernity, Religion, and Democracy. New York: Monthly Review Press. 
Aron, R. (1967). Main Currents in Sociological Thought. Harmondsworth: Penguin.

Barnes, H. E., \& Becker, H. (1938). Social Thought from Lore to Science. London: D.C.Health and Company.

Berger, P. (1967). Invitation to Sociology A Humanistic Perspective. Harmondsworth: Penguin.

Brook, T., \& Blue, G. (1999). China and Historical Capitalism. Cambridge: Cambridge University Press. https://doi.org/10.1017/CBO9780511470707

Evans-Pritchard, E. E. (1981). A History of Anthropological Thought. London: Faber and Faber.

Gellner, E. (1983). Muslim Society. Cambridge: Cambridge University Press.

Giddens, A. (2001). Sociology (6th ed.). Cambridge: Polity Press.

Goody, J. (2006). The Theft of History. Cambridge: Cambridge University Press.

Haller, M. (2015). Ethnic Stratification and Economic Inequality around the World. Surrey, England: Ashgate.

Khaldun, I. (1958). The Muquaddimah: An Introduction to History. Translated by Franz Rosenthal, 3 vols. London: Routledge and Kegan Paul.

Manuel, F. (1962). The Prophets of Paris. Cambridge: Cambridge University Press.

Menocal, M. R. (2009). The Finest Flowering Poetry, History and Medieval Spain in the $21^{\text {st }}$ Century. In K. Malette, \& S. Akbari (Eds.), A Sea of Languages: Rethinking Arabic Role in Medieval Literary History. Toronto: University of Toronto Press.

Momin, A. R. (2015). Ibn Khaldun: The Founder of Sociology. Retrieved March 10, 2018, from http://www.iosminaret.org/vol-9/issue22/Ibn_Khaldun.php

Nisbet, R. (1967). The Sociological Tradition. London: Heinermann.

Ritzer, G. (1992). Sociological Theories (3rd ed.). New York: McGraw-Hill.

Sorokin, P. (1962). Society, Culture and Personality. New York: Cooper Square Publishers.

Toynbee, A. J. (1962). A Study of History. Oxford: Oxford University Press.

Turner, J. H. (1989). Sociology in the US: Its growth and contemporary profile. In N. Genor, (Ed.), National Traditions in Sociology (pp. 220-242). London: Sage.

Vidich, A. J., \& Lyman, S. M. (1985). American Sociology: Worldly Rejections of Religion and their Directions. New Haven, Conn: Yale University Press.

Wells, R. H., \& Picou, S. J. (1981). American Sociology: Theoretical and Methodological Structure. Washington DC. University Press of America.

Winckelmann, J. J. (1768). History of the Art of Antiquity. USA: Getty Research Institute.

\section{Copyrights}

Copyright for this article is retained by the author(s), with first publication rights granted to the journal.

This is an open-access article distributed under the terms and conditions of the Creative Commons Attribution license (http://creativecommons.org/licenses/by/4.0/). 